\title{
Effect of iron in zinc silicate concentrate on leaching with sulphuric acid
}

\author{
A.D. Souza ${ }^{\text {a }}$, P.S. Pina ${ }^{\text {b }}$, F.M.F. Santos ${ }^{\text {b }}$, C.A. da Silva ${ }^{\text {b }}$, V.A. Leão ${ }^{\text {b, } *}$ \\ ${ }^{a}$ Votorantim Metais Zinc. BR 040, Km 284 - CEP 39.205-000, Três Marias, MG, Brazil

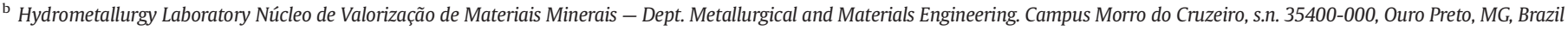

\section{A R T I C L E I N F O}

\section{Article history:}

Received 13 September 2007

Received in revised form 28 May 2008

Accepted 30 May 2008

Available online 17 June 2008

\section{Keywords:}

Zinc silicate

Willemite

Leaching

Iron content

Kinetics

Zinc recovery

\begin{abstract}
A B S T R A C T
It is shown that the iron content in zinc silicate concentrates with either high (8-11\%) or low (3\%) iron does not significantly affect the kinetics or overall recovery of zinc extraction in sulphuric acid. Most of the iron was present as hematite and franklinite with little iron contained in willemite. A small reduction in zinc recovery from $98.5 \%$ to $97.5 \%$ was observed for silicate ores containing $12 \%$ iron. The activation energy determined from high-iron concentrate leaching, $78 \pm 12 \mathrm{~kJ} / \mathrm{mol}$, is statistically similar to that from low-iron concentrate, $67 \pm 10 \mathrm{~kJ} / \mathrm{mol}$, suggesting the same rate-controlling step. The leaching of high high-iron concentrates enables a higher mass recovery during flotation. A flowsheet is proposed comprising a magnetic separation step to produce a magnetic and a non-magnetic product so that iron dissolution from the magnetic concentrate acts as a source of soluble iron for impurities removal.
\end{abstract}

(c) 2008 Elsevier B.V. All rights reserved.

\section{Introduction}

The roasting of zinc sulphide concentrates produces zinc, iron and other metal oxides (known as calcine), which are readily leached in sulphuric acid solutions (Çopur et al., 2004), with zinc ferrites one of the major species in the leaching residues (Youcai and Stanforth, 2000). These ferrites can be very refractory to chemical attack and one method for their zinc recovery is to leach these residues with hot, concentrated sulphuric acid solutions, although this step will always dissolve a considerable amount of iron. This also requires a large quantity of acid during leaching and then a series of downstream iron and impurity metal removal steps (Youcai and Stanforth, 2000). Several processes to remove dissolved iron have been applied at zinc industries, such as the jarosite $\left[\mathrm{XFe}_{3}\left(\mathrm{SO}_{4}\right)_{2}(\mathrm{OH})_{6}\right]$, goethite $(\mathrm{FeOOH})$, hematite $\left(\mathrm{Fe}_{2} \mathrm{O}_{3}\right)$ and paragoethite (ferrihydrite) processes; each of them having its own advantages and disadvantages (Pappu et al., 2006). Notwithstanding, a small iron concentration in the zinc process is beneficial. Raghavan et al. (1998) have proposed that there are two major steps to remove impurities from the zinc sulphate solution to those levels required for the electrolyte. The first stage takes place in the neutral leaching step where co-precipitation of several deleterious impurities such as antimony, arsenic and germanium occurs, along

\footnotetext{
* Corresponding author. Tel.: +55 313559 1102; fax: +55 3135591561 .

E-mail addresses: adelson.souza@vmetais.com.br (A.D. Souza), versiane@demet.em.ufop.br, va.leao@uol.com.br (V.A. Leão).
}

with that of iron hydroxide (Eq. (1). The second step comprises cementation with zinc dust.

$$
\begin{aligned}
2 \mathrm{FeSO}_{4} & +3 \mathrm{ZnO}+\mathrm{MnO}_{2}+2 \mathrm{H}_{2} \mathrm{SO}_{4}+\mathrm{H}_{2} \mathrm{O} \rightarrow 2 \mathrm{Fe}(\mathrm{OH})_{3} \\
& +3 \mathrm{ZnSO}_{4}+\mathrm{MnSO}_{4}
\end{aligned}
$$

In the case of silicate concentrates, Souza (2000) has devised an integrated process to treat zinc silicate concentrates in the same plant that processes zinc sulphide concentrates by the RLE process (the integrated process). Among the different options available, the author has suggested only one step of zinc silicate leaching where stepwise addition of sulphuric acid dissolves the silicate with a minimum silica gel formation. The neutralisation of the residual acidity with lime or limestone to $\mathrm{pH} 4.0$ provides good settling and filtration properties of the leaching residue. This leaching approach, industrially applied at the Três Marias Zinc facility, presents high zinc recovery (>98\%), treating 350,000 tonnes/year of zinc silicate concentrate (Brook-Hunt, 2005). Although there is no reference to the iron influence during leaching in the integrated process, the interest for the hydrometallurgical processing of high high-iron silicate concentrates appeared when the Vazante Mine in Brazil noticed the occurrence of high-iron silicate ores that would be submitted to the flotation step, which precedes the hydrometallurgical treatment.

The purpose of the present work is to examine the effect of the iron content in the concentrates on both zinc dissolution kinetics and recovery. A new treatment flowsheet is proposed using the iron content in the concentrate to eliminate impurities. 


\section{Materials and methods}

The chemical analysis of both the high- and low-iron flotation concentrates is presented in Table 1. The high-iron concentrate contains $34-39 \% \mathrm{Zn}$ and $8-11 \% \mathrm{Fe}$, whereas the low-iron sample has more zinc (46\%) and less iron ( $3 \%)$. Prior to the leaching experiments, these concentrates were dry ground and wet sieved to yield a particle size distribution between 150 and $38 \mu \mathrm{m}$. Zinc and iron contents, surface area, total porous volume and average pore diameter of the sieved fractions are also presented in Table 1.

For the kinetics study, chemical leaching experiments were carried out batch-wise with $10 \mathrm{~g} / \mathrm{L}$ solids in $500 \mathrm{~mL}$ solution in a closed waterjacketed borosilicate glass reactor ( $750 \mathrm{~mL}$ total volume) agitated by a magnetic stirrer. This enabled adequate dispersion of the mineral particles without evaporation loss of the solution. Leach solutions were prepared using reagent grade $\mathrm{H}_{2} \mathrm{SO}_{4}$ and distilled water. At selected time intervals, a known amount $(3 \mathrm{~mL})$ of slurry was withdrawn, filtered and analysed for zinc in solution (Atomic Absorption Spectrometry, Perkin Elmer AAnalyst 100) to determine zinc extraction. The volume change was taken into account for the zinc extraction determinations.

Batch leaching experiments under industrial conditions $(150 \mathrm{~g} / \mathrm{L}$ solids; $70 \pm 2{ }^{\circ} \mathrm{C} ; 7 \mathrm{~h}$ retention time; $35 \mathrm{~g} / \mathrm{L}$ final acid concentration and $2.75 \mathrm{~L}$ total volume) were also carried out to determine zinc extraction from three different zinc flotation concentrates, assaying 5\%, $9 \%$ and $12 \%$ iron. These experiments aimed to confirm those results achieved during the kinetic studies with low solid concentrations and pulp volume.

Surface area and pore volume were determined by nitrogen adsorption. Nitrogen isotherms were performed with a Nova 1000 High Speed Gas Sorption Analyzer (Quantachrome). Sample degassing was carried out at $80{ }^{\circ} \mathrm{C}$, for $24 \mathrm{~h}$, to avoid decomposition. Nitrogen adsorption was performed at $-196{ }^{\circ} \mathrm{C}$. Data were collected from a relative pressure $\left(p / p_{0}\right)$ of 0.05 to 0.98 . A large sample $(\sim 4.0 \mathrm{~g})$ was used and the Nova 1000 parameters (equilibration tolerance, time to remain in tolerance and maximum equilibration time) were set at $0.05,360$ and 720 , respectively, to improve the accuracy of low surface area measurements with nitrogen adsorption.

X-ray diffraction was carried out on a Shimadzu 600 diffractometer equipped with an iron tube and graphite monochromator. Willemite was identified as the main mineral phase; with quartz, hematite and hemimorphite also present as minor phases in the low-iron concentrate; while franklinite and dolomite, but not hemimorphite, were observed in the high-iron concentrate. Therefore zinc in this concentrate is associated with willemite and franklinite (a minor species)

Table 1

Chemical analysis ( $\mathrm{Zn}$ and Fe) and surface parameters of different screened fractions of low- and high-iron zinc silicate concentrates

\begin{tabular}{|c|c|c|c|c|c|c|c|}
\hline & & Unit & $\begin{array}{l}150- \\
105 \mu \mathrm{m}\end{array}$ & $\begin{array}{l}105- \\
75 \mu \mathrm{m}\end{array}$ & $\begin{array}{l}75- \\
53 \mu \mathrm{m}\end{array}$ & $\begin{array}{l}53- \\
45 \mu \mathrm{m}\end{array}$ & $\begin{array}{l}45- \\
38 \mu \mathrm{m}\end{array}$ \\
\hline \multirow{6}{*}{$\begin{array}{l}\text { High-iron } \\
\text { silicate } \\
\text { concentrate }\end{array}$} & Zn & (\%) & 39.4 & 39.7 & 35.6 & 35.2 & 34.1 \\
\hline & $\mathrm{Fe}$ & (\%) & 8.0 & 9.8 & 11.7 & 10.3 & 11.1 \\
\hline & $\mathrm{SiO}_{2}$ & (\%) & 25.1 & 24.3 & 23.8 & 23.2 & 22.9 \\
\hline & Surface area & $\mathrm{m}^{2} / \mathrm{g}$ & 1.2 & 1.0 & 0.6 & 0.6 & 1.0 \\
\hline & $\begin{array}{l}\text { Total porous } \\
\text { volume }\end{array}$ & $\mathrm{mm}^{3} / \mathrm{g}$ & 3.6 & 3.3 & 2.5 & 2.5 & 2.5 \\
\hline & $\begin{array}{l}\text { Pore average } \\
\text { diameter }\end{array}$ & $\mathrm{Nm}$ & 12.1 & 13.1 & 17.9 & 18.0 & 9.8 \\
\hline \multirow{6}{*}{$\begin{array}{l}\text { Low-iron } \\
\text { silicate } \\
\text { concentrate }\end{array}$} & $\mathrm{Zn}$ & (\%) & 46.9 & 46.0 & 46.9 & 46.6 & 47.3 \\
\hline & $\mathrm{Fe}$ & (\%) & 3.74 & 2.92 & 3.19 & 3.02 & 3.25 \\
\hline & $\mathrm{SiO}_{2}$ & (\%) & 29.4 & 29.5 & 29.6 & 30.1 & 25.9 \\
\hline & Surface area & $\mathrm{m}^{2} / \mathrm{g}$ & 0.8 & 0.5 & 0.5 & 0.5 & 0.7 \\
\hline & $\begin{array}{l}\text { Total porous } \\
\text { volume }\end{array}$ & $\mathrm{mm}^{3} / \mathrm{g}$ & 3.5 & 1.4 & 1.3 & 2.1 & 1.3 \\
\hline & $\begin{array}{l}\text { Pore average } \\
\text { diameter }\end{array}$ & $\mathrm{Nm}$ & 17.6 & 11.6 & 10.8 & 15.8 & 7.4 \\
\hline
\end{tabular}

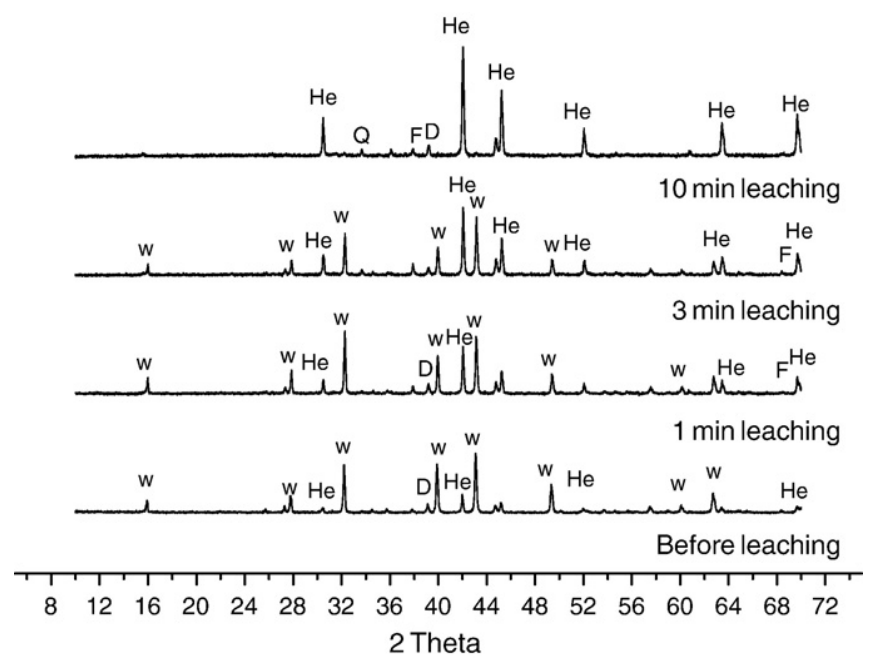

Fig. 1. XRD pattern of the high-iron zinc silicate concentrate. Q: quartz, He: hematite, w: willemite, F: franklinite, D: dolomite.

(Figs. 1 and 2). Quantitative mineralogy was carried out by transmitted light microscopy (Leica).

The analyses of both concentrates and leach residues were also carried out by SEM-EDS. The samples were coated with graphite by electro-deposition, using a Jeol JEE 4C instrument and observed in a JEOL JSM 5510 scanning electron microscope (SEM), equipped with a spectrometer for micro-analysis, based on an Energy Dispersive X-ray Spectroscopy System (EDS) and having an accelerating voltage of 0.5$30 \mathrm{kV}$. Electron microprobe analysis confirmed willemite as the main zinc mineral since the metal content of different grains is similar to that of a pure mineral (theoretical, Table 2 and Fig. 3). Iron is not present in the willemite structure, as shown in Fig. 3(b).

\section{Results and discussion}

\subsection{Effect of leaching parameters}

The effect of the agitation speed on zinc extraction for the high- and low-iron concentrates was assessed in the range $360-720 \mathrm{rpm}$. The stirring rate did not affect the zinc extraction regardless of the iron content in both concentrates. Therefore, the dissolution process did not seem to be controlled by mass transfer through the liquid boundary film, despite the possible change in solution viscosity caused by silica

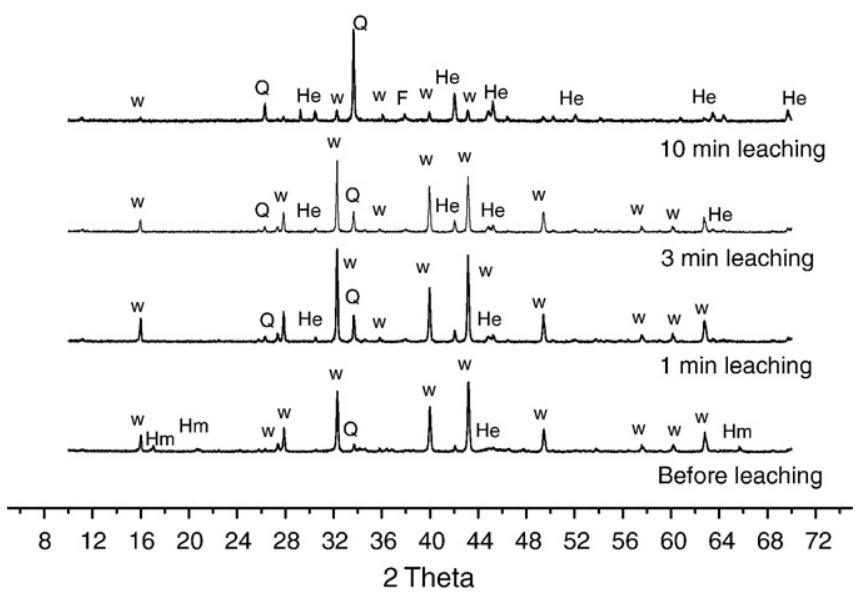

Fig. 2. XRD pattern of the low-iron zinc silicate concentrate. Q: quartz, He: hematite, w: willemite, F: franklinite, Hm: hemimorphite. 
Table 2

EDS analysis (Zn, Si and O) of the zinc silicate calcine (average of 6 points)

\begin{tabular}{lll}
\hline Element & EDS analysis (\%) & Pure willemite (\%) \\
\hline $\mathrm{Zn}$ & 55.97 & 58.67 \\
$\mathrm{Si}$ & 12.56 & 12.61 \\
$\mathrm{O}$ & 31.57 & 28.72 \\
\hline
\end{tabular}

gel formation. Unless otherwise stated, the stirring speed was kept at $600 \mathrm{rpm}$.

Figs. 4 and 5 show that zinc extraction as a function of temperature, for the high- and low-iron materials, is fast in the range 10$70{ }^{\circ} \mathrm{C}$ - occurring in less than $600 \mathrm{~s}$ for the high-iron sample and slightly slower for the low-iron concentrate. Furthermore, temperature has an important influence on the zinc extraction rate, irrespective of the iron content in the concentrate samples. Similar results were observed by Bodas (1996) and Espiari et al. (2006) with a zinc silicate containing hemimorphite $\left(\mathrm{Zn}_{4} \mathrm{Si}_{2} \mathrm{O}_{7}(\mathrm{OH})_{2} \times \mathrm{H}_{2} \mathrm{O}\right)$ and smithsonite $\left(\mathrm{ZnCO}_{3}\right)$ as major zinc minerals. Abdel-Aal (2000) also studied the leaching of a zinc silicate ore containing willemite and hemimorphite as major zinc phases and small amounts of smithsonite and observed increased zinc extraction from $70 \%$ to $95 \%$ upon increasing the temperature from 40 to $70{ }^{\circ} \mathrm{C}$. Similarly, Souza et al. (2007) verified the influence of temperature on leaching a zinc silicate calcine in the range $30-60{ }^{\circ} \mathrm{C}$.

Figs. 6 (high-iron) and 7 (low-iron) present the effect of sulphuric acid concentration on the rate of zinc extraction. In both cases, zinc extraction increases gradually with the sulphuric acid concentration, in the range 0.1 to $1 \mathrm{~mol} / \mathrm{L} \mathrm{H}_{2} \mathrm{SO}_{4}$. This behaviour was observed in
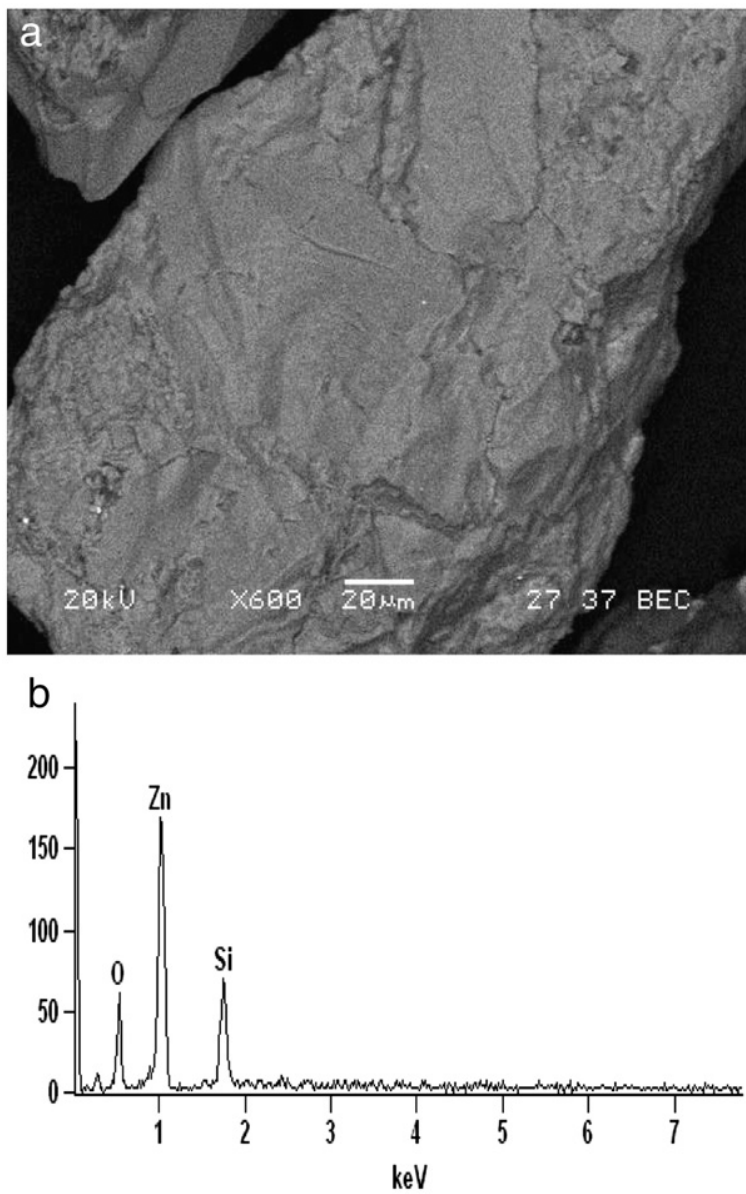

Fig. 3. Willemite particle (a) and its EDS spectrum (b) showing the presence of oxygen, zinc and silicon as the only elements in the mineral particle.

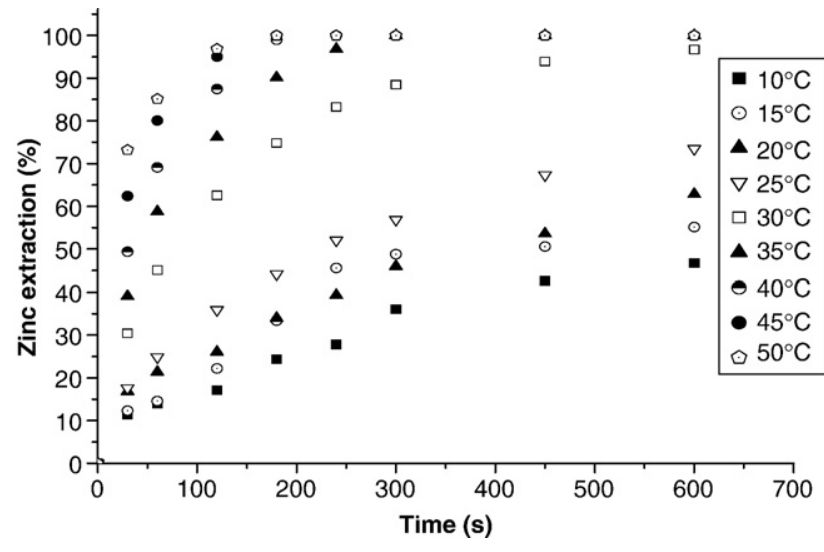

Fig. 4. Effect of temperature on zinc extraction for the high-iron silicate. $0.4 \mathrm{~mol} / \mathrm{L}$ $\mathrm{H}_{2} \mathrm{SO}_{4}, 10 \mathrm{~g} / \mathrm{L}$ solids, agitation speed $600 \mathrm{rpm}$ and particle size $75-53 \mu \mathrm{m}$.

previous work carried out by Bodas (1996), Abdel-Aal (2000), Espiari et al. (2006) and Souza et al. (2007). Terry and Monhemius (1983) also studied the effect of sulphuric, nitric, phosphoric and hydrochloric acid concentrations upon the zinc dissolution from a willemite sample and observed that the rate of zinc dissolution was strongly dependent on the acid concentration and the anion $\left(\mathrm{SO}_{4}^{2-}, \mathrm{PO}_{4}^{3-}, \mathrm{Cl}^{-}\right.$and $\left.\mathrm{NO}_{3}^{-}\right)$. It was suggested that the difference in the reactivity order was a function of the affinity to complex with the zinc ion. In spite of the higher leaching rate observed in the hydrochloric acid medium, the present work was carried out with sulphuric acid solutions, since this is the standard reagent in industrial practices.

The effect of the particle size upon zinc extraction is presented in Figs. 8 and 9. The decrease in particle size enhanced zinc dissolution at the beginning of the experiments, but it can be noticed that such fast leaching reactions are not affected by the particle size over practical leaching times since zinc extractions are about the same irrespective of the size fraction studied.

The morphology of both the high- and low-iron zinc silicate flotation concentrates before and after 1, 3, and 10 min of leaching was examined by SEM-EDS and presented in Fig. 10 for the zinc-containing phases. The micrographs of the high-iron material are presented in the first column (A) and those of the low-iron, depicted in the second column (B). The solid particles before leaching present a natural rough surface, as observed in Fig. 10(A.1) and (B.1). The leaching residues show a progressive increase in the roughness and porosity, regardless of the iron content in the concentrate (Fig. 10(A.2) to (A.4) and (B.2) to (B.4)). In spite of the surface degradation generated by the leaching process, the SEM-EDS analysis suggests that the particle surface does

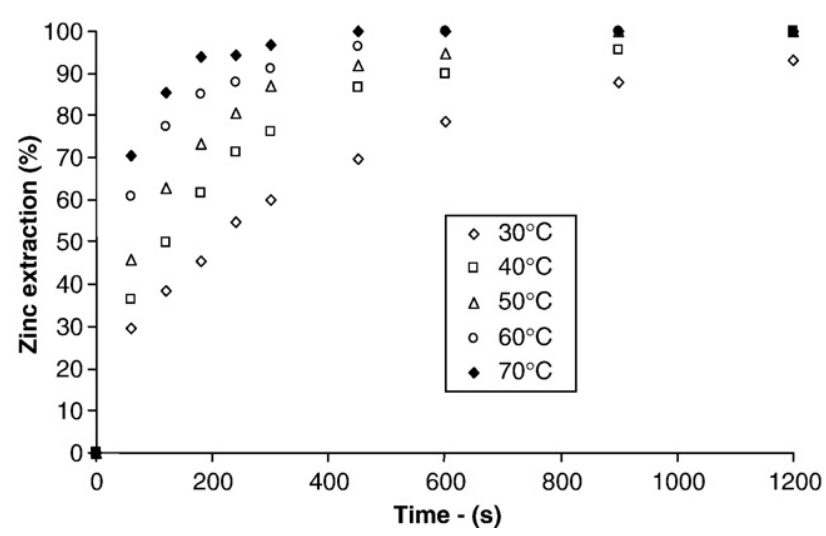

Fig. 5. Effect of temperature on zinc extraction for the low-iron silicate. $0.4 \mathrm{~mol} / \mathrm{L} \mathrm{H}_{2} \mathrm{SO}_{4}$, $10 \mathrm{~g} / \mathrm{L}$ solids, agitation speed $600 \mathrm{rpm}$ and particle size $75-53 \mu \mathrm{m}$. 


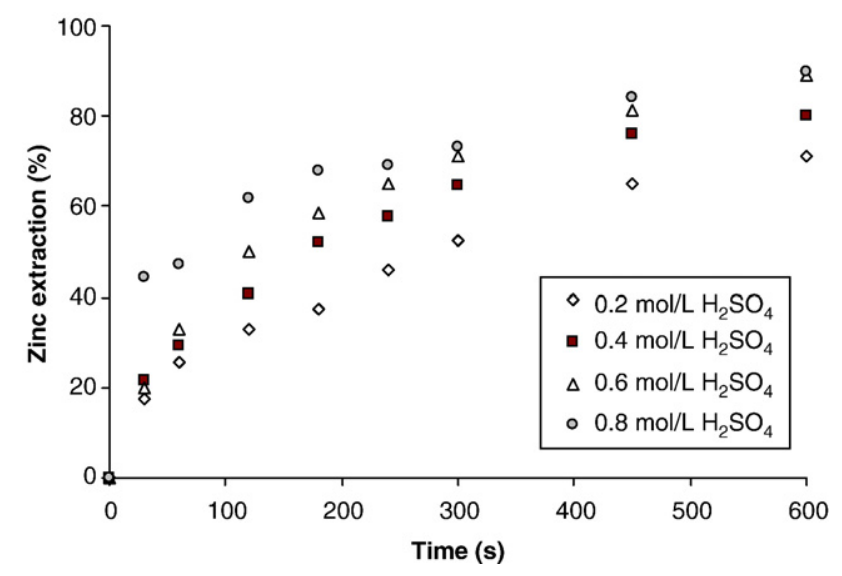

Fig. 6. Effect of acid concentration on zinc extraction from the high-iron content silicate. Stirring speed $600 \mathrm{rpm}, 10 \mathrm{~g} / \mathrm{L}$ solids, temperature $25{ }^{\circ} \mathrm{C}$ and particle size $75-53 \mu \mathrm{m}$.

not present any reaction product layer. Willemite progressively disappears while the less soluble phases, quartz and hematite, predominate at the later stages of leaching.

\subsection{Kinetics analysis}

In previous work, Souza et al. (2007) discussed the application of different kinetic models to the leaching of porous materials and observed that the grain model with pore diffusion control could successfully describe the dissolution kinetics of a zinc silicate concentrate. This model considers that the solid reactant is made up of a large number of individual grains of the same size and form, which are similar to the exterior form of the particle (i.e. a spherical particle is formed by spherical non-porous grains). When the chemical reaction resistance is negligible, as compared to that due to pore diffusion, the reaction occurs in a narrow region and this situation is similar to the shrinking core model with ash layer control, applied to non-porous solids (Szekely et al., 1976). In this condition, the model gives the following expression describing the leaching rate of spherical particles (Georgiou and Papangelakis, 1998):

$1-3(1-\alpha)^{\frac{2}{3}}+2(1-\alpha)=k_{\mathrm{D}} t \quad$ where $k_{\mathrm{D}}=\frac{3 b D_{\text {eff }}\left[\mathrm{H}_{2} \mathrm{SO}_{4}\right]^{n}}{r_{0}^{2} \rho_{\text {silicate }}\left(1-\varepsilon_{0}\right)}$

where $\alpha$ stands the fractional conversion; $k_{\mathrm{D}}$, for kinetic parameter for pore diffusion control; $b$, for stoichiometric coefficient; $\rho_{\text {silicate, for }}$ molar density of the silicate; $r_{0}$, for particle radius; $n$ order of reaction

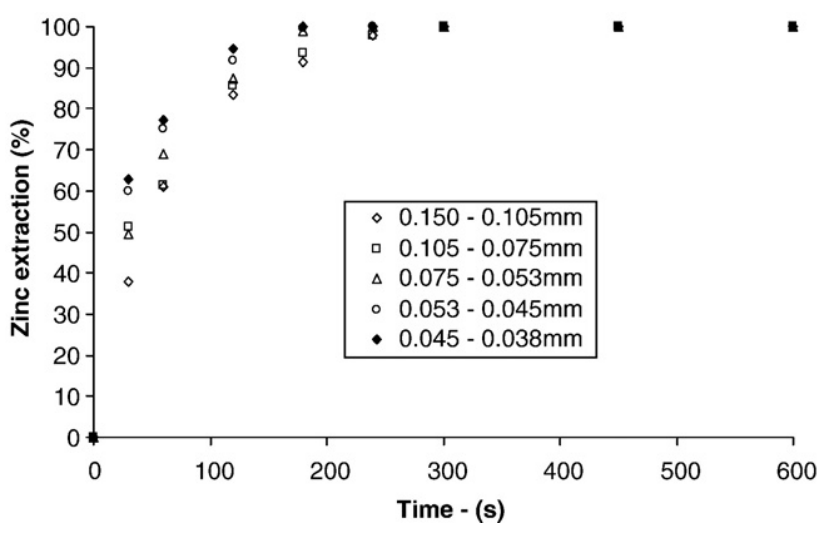

Fig. 8. Effect of particle size on zinc extraction from the high-iron content silicate. (stirring speed $600 \mathrm{rpm}, 10 \mathrm{~g} / \mathrm{L}$ solids, temperature $40{ }^{\circ} \mathrm{C}$ and $0.4 \mathrm{~mol} / \mathrm{L} \mathrm{H}_{2} \mathrm{SO}_{4}$ ).

with respect to sulphuric acid; $D_{\text {eff }}$, for effective diffusion coefficient, $\varepsilon_{0}$ for particle porosity and $\left[\mathrm{H}_{2} \mathrm{SO}_{4}\right]$ for the acid concentration.

In the present work, the zinc silicate leaching kinetics for both the low- and high-iron concentrates also fitted the grain model with porous diffusion control, Eq. (2), $\left(r^{2}>0.98\right)$ at different temperatures. Fig. 11 presents the Arrhenius plot produced from the rate constant values $\left(k_{\mathrm{D}}\right)$ achieved. The activation energy determined for the high-iron material ( $78 \pm 12 \mathrm{~kJ} / \mathrm{mol}$ ) is statistically similar to that observed for the low-iron concentrate $(67 \pm 10 \mathrm{~kJ} / \mathrm{mol})$. This suggests that the leaching of both solids presents the same rate-controlling-step (i.e. diffusion on the particle pores), as observed by Souza et al. (2007) for a similar zinc concentrate. Souza et al. (2007) also determined an activation energy value of $52 \pm 3 \mathrm{~kJ} / \mathrm{mol}$ for the dissolution kinetics of a calcined sample of the low-iron zinc silicate, which is slightly lower than the values observed in this work. Similarly, Terry and Monhemius (1983) reported a value of $49 \mathrm{~kJ} / \mathrm{mol}$ for the chemically controlled dissolution of willemite in sulphuric acid solution. The pore model considers diffusion and chemical reaction in porous solids in parallel and therefore the overall reaction rate of the process is always proportional to the reaction rate of the chemical step, even if the process is not chemically controlled (Sohn and Wadsworth, 1979; Souza et al., 2007). This implies that the apparent activation energy is the average of that for intrinsic reaction and diffusion. The reaction order (Fig. 12) was determined as $0.58 \pm 0.18$ and $0.54 \pm 0.13$ for the high- and low low-iron silicates respectively. These values are also influenced by the parallel nature of the chemical reaction and diffusion and the values observed corroborate the finding that the dissolution of the high- and low-iron concentrates has the same rate-determining step.

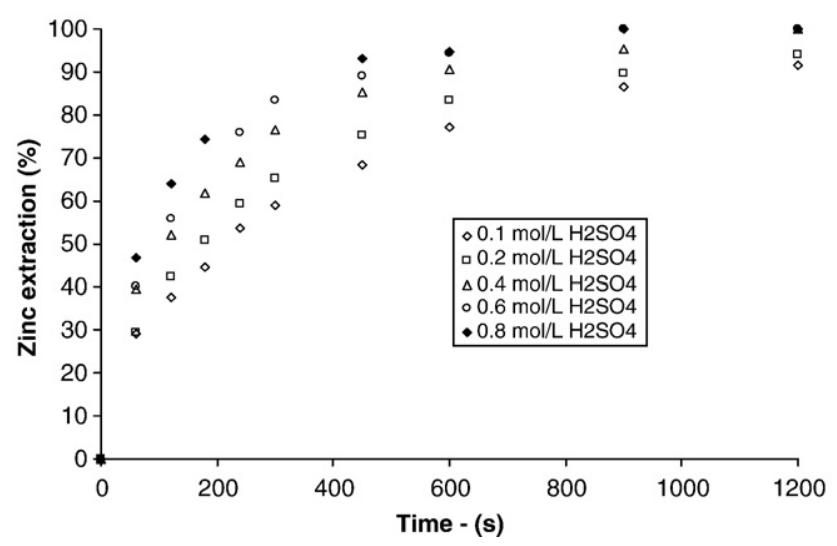

Fig. 7. Effect of acid concentration on zinc extraction from the low-iron silicate. Stirring speed $600 \mathrm{rpm}, 10 \mathrm{~g} / \mathrm{L}$ solids, temperature $30{ }^{\circ} \mathrm{C}$ and particle size $75-53 \mu \mathrm{m}$.

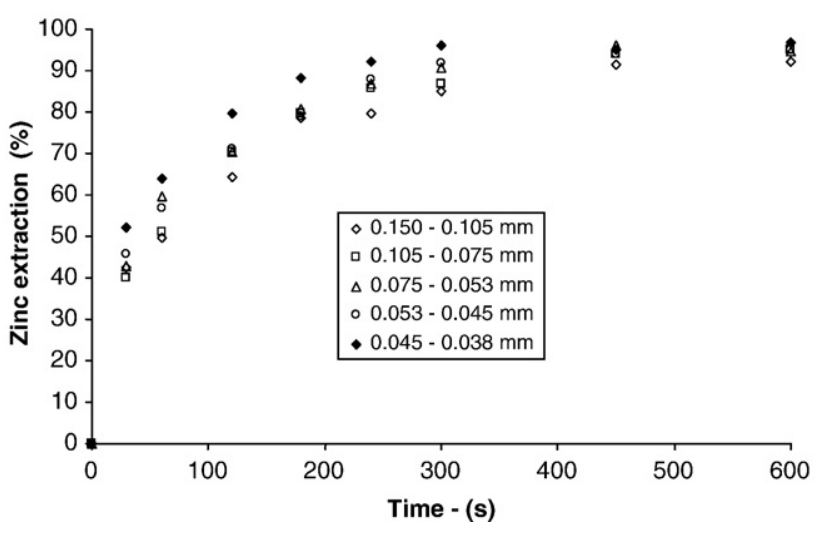

Fig. 9. Effect of particle size on zinc extraction from the low-iron content silicate. (Stirring speed $600 \mathrm{rpm}, 10 \mathrm{~g} / \mathrm{L}$ solids, temperature $40{ }^{\circ} \mathrm{C}$ and $0.4 \mathrm{~mol} / \mathrm{L} \mathrm{H}_{2} \mathrm{SO}_{4}$ ). 

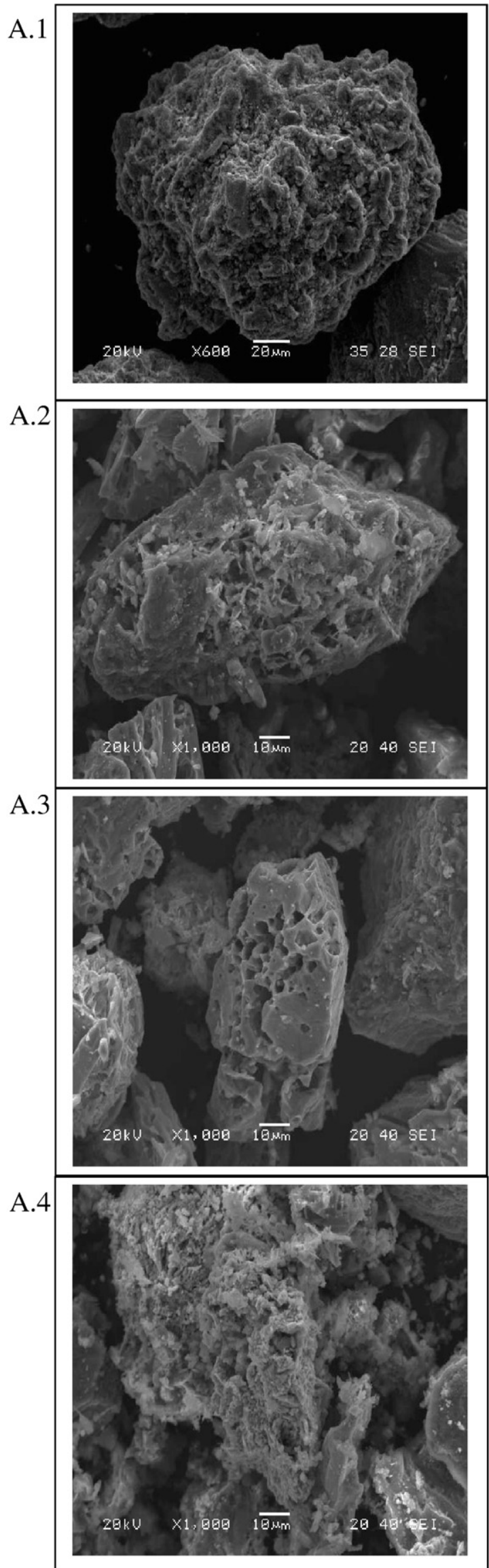

B. 1

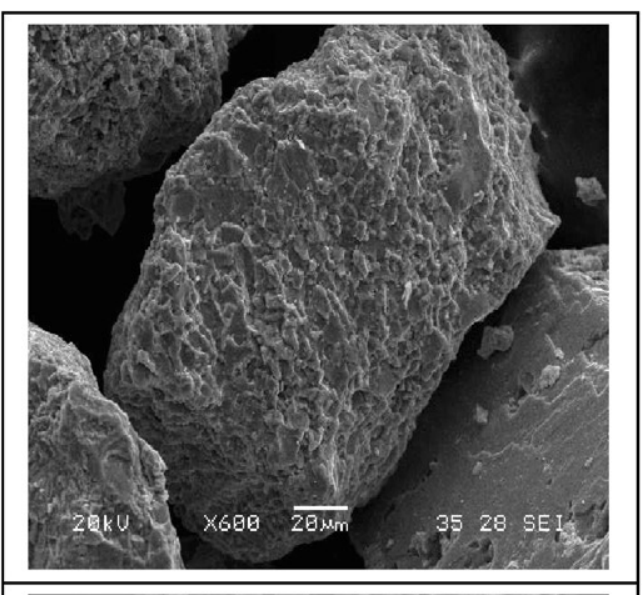

B. 2

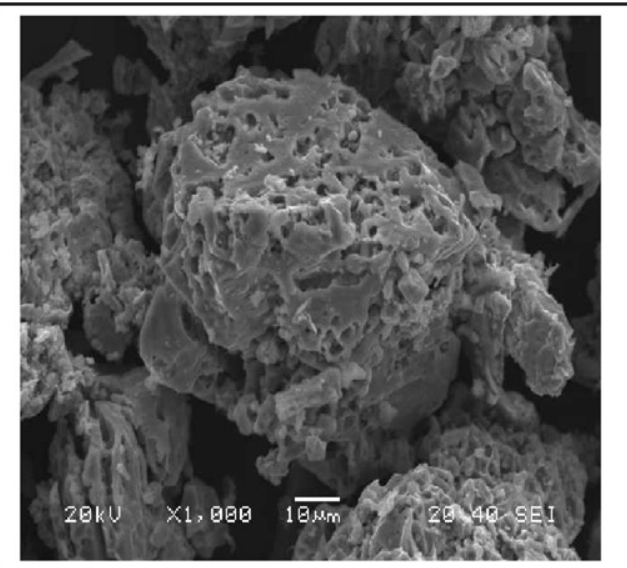

B. 3
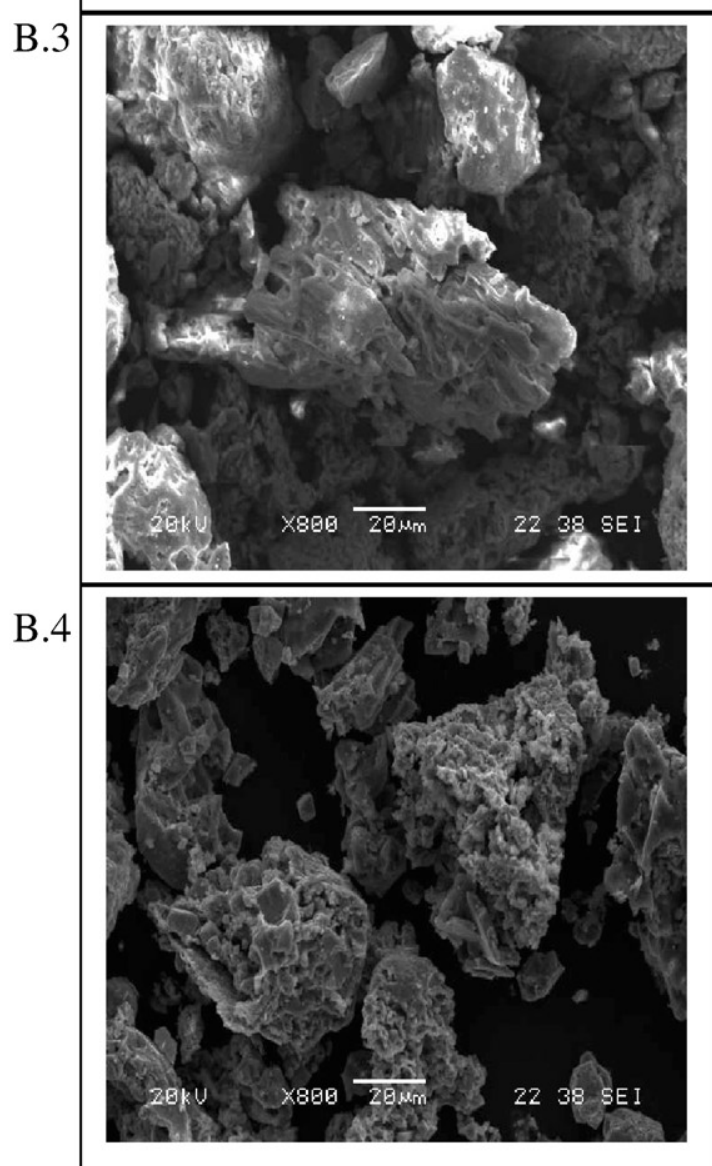

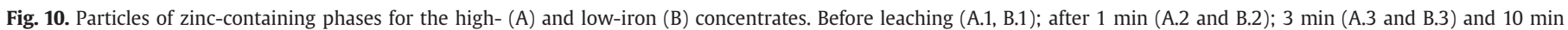
(A.4 and B.4). 


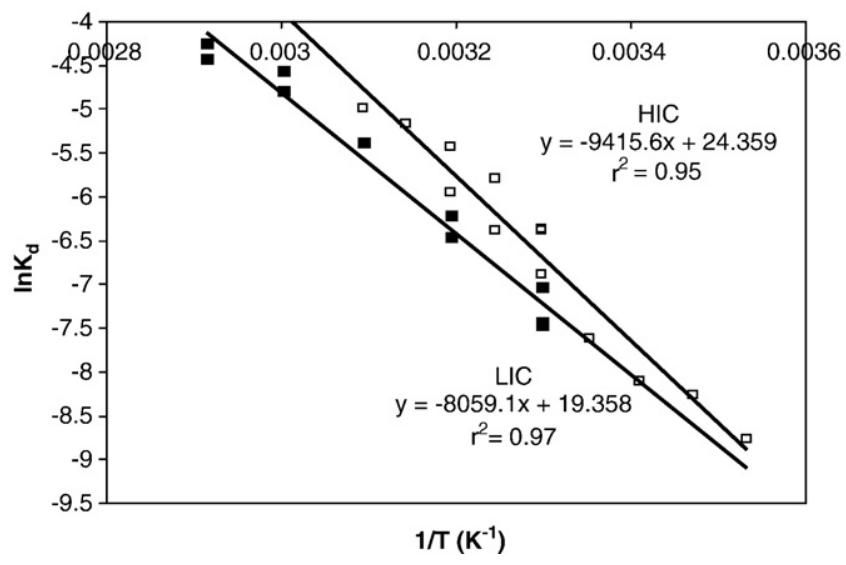

Fig. 11. Arrhenius plot of the leaching of both the high- (HIC) and low-iron (LIC) zinc silicates. Agitation speed $600 \mathrm{rpm}, 0.4 \mathrm{~mol} / \mathrm{L} \mathrm{H}_{2} \mathrm{SO}_{4}, 10 \mathrm{~g} / \mathrm{L}$ solids (w/v) and particle size 75-53 $\mu \mathrm{m}$.

\subsection{Statistical significance of iron content in leaching of zinc silicate concentrate}

Experiments were carried out with three zinc silicate concentrates assaying $5 \%, 9 \%$ and $12 \%$ iron so that the effect of iron content in the concentrate during zinc leaching was determined. These experiments were carried out under similar conditions of acid concentration, leaching time, solid content and temperature to those currently performed at the Três Marias Zinc facilities in Brazil. Table 3 presents both zinc and iron extractions as a function of iron content in the zinc concentrate. High zinc extractions (>97\%) were observed in all experiments, regardless of the iron level in the concentrate; while iron dissolution was higher for the concentrate with lower iron content, derived mainly from hematite dissolution (Table 4). The analysis of variance (ANOVA) and the Tukey pair-wise comparisons of the average zinc extractions for the $5 \%$ and $12 \%$ iron concentrates indicate that the iron content of the concentrate statistically affects the zinc leaching $\left(f_{0}>f_{0.05 ; 2 ; 12}\right.$ or $31.88>3.89$ and $P<\alpha$ or $0.000<0.05$ ). Notwithstanding, increasing the iron content from $5 \%$ to $9 \%$ iron does not result in a statistically significant reduction in zinc extraction. The relevance of these results for the industrial practice will be discussed below.

\subsection{Industrial implications of iron in the silicate concentrates}

Low Low-iron content is a drawback for the processing of zinc silicate concentrates as iron plays an important role during the removal of impurities such as arsenic, germanium and antimony (Raghavan

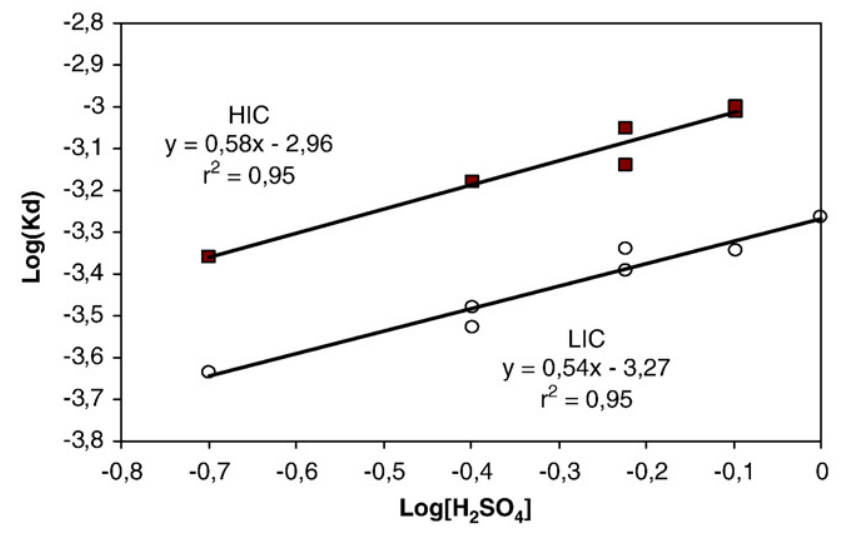

Fig. 12. Determination of reaction order with respect to sulphuric acid. Agitation speed $600 \mathrm{rpm}, 10 \mathrm{~g} / \mathrm{L}$ solids (w/v), temperature $25^{\circ} \mathrm{C}$ (high-iron content), temperature $30{ }^{\circ} \mathrm{C}$ (low-iron content) and particle size $75-53 \mu \mathrm{m}$. HIC - high iron concentrate; LIC low iron concentrate
Table 3

Zinc and iron extraction according to iron content in zinc silicate concentrate

\begin{tabular}{|c|c|c|c|c|c|c|}
\hline \multirow[t]{2}{*}{ Experiments } & \multicolumn{3}{|c|}{ Zinc extraction (\%) } & \multicolumn{3}{|c|}{ Iron extraction (\%) } \\
\hline & $5 \% \mathrm{Fe}$ & $9 \% \mathrm{Fe}$ & $12 \% \mathrm{Fe}$ & $5 \% \mathrm{Fe}$ & $9 \% \mathrm{Fe}$ & $12 \% \mathrm{Fe}$ \\
\hline 1 & 98.5 & 98.4 & 97.8 & 13.1 & 31.2 & - \\
\hline 2 & 99.0 & 98.6 & 98.0 & 31.3 & 36.2 & 19.7 \\
\hline 3 & 98.9 & 98.9 & 97.7 & 24.1 & 15.0 & 11.2 \\
\hline 4 & 98.7 & 98.6 & 97.7 & 16.2 & 17.7 & 14.5 \\
\hline 5 & 98.7 & 98.4 & 97.4 & 20.7 & - & 17.8 \\
\hline Mean & 98.7 & 98.6 & 97.7 & 21.1 & 25.2 & 15.8 \\
\hline Standard deviation & 0.22 & 0.20 & 0.24 & 7.1 & 10.4 & 3.7 \\
\hline
\end{tabular}

et al., 1998). The integrated technology to treat zinc silicate concentrates along with zinc sulphide calcines (Souza, 2000) applied at the Três Marias facility, uses the concept of impurities removal by adsorption onto ferric hydroxide during the neutral leaching of calcines $(\mathrm{ZnO})$ produced from zinc sulphide roasting. This is achieved as the pregnant solution produced during acid leaching (containing $35 \mathrm{~g} / \mathrm{L}$ final acidity) is sent to the calcine treatment step, where the higher $\mathrm{pH}$ ( $\mathrm{pH} 4-4.5)$ causes iron precipitation along with impurity removal. This approach is cost-effective in the zinc industry (BrookHunt, 2005).

It is well known that a series of strong acid leaching steps are required to achieve high zinc recoveries from sulphide concentrates with high-iron content due to the formation of zinc ferrites during roasting of such sulphides (Brook-Hunt, 2005). As the silicate also contains a natural form of zinc ferrites (franklinite), the same behaviour would be expected for zinc silicate flotation concentrates when the iron level is increased. Nevertheless, it is shown in the present work, through the kinetic study of high- and low-iron flotation concentrates, that the leaching of both materials is similar. This is an important finding for zinc silicate facilities, because the specification of the rawmaterial could be less restrictive, so that high-iron silicate concentrates could be processed containing up to $12 \%$ iron. The present work shows that concentrates with $12 \%$ iron did not show any appreciable reduction in zinc recovery as compared to those with $5 \%$ or $9 \%$ iron. Therefore, the leaching step need not be changed on moving from a zinc sulphide treatment plant to a zinc silicate processing facility or when the iron content in the flotation concentrate increases with time. This contributes to savings in capital and operating expenditure.

It was further noted from pilot-plant flotation experiments carried out with these zinc silicates, that when the iron content in the concentrate was increased and zinc content was reduced, the overall zinc recovery in the flotation step improved, as shown in Fig. 13. In those zinc leaching facilities integrated with ore concentration plants,

Table 4

Chemical analysis of zinc concentrates produced during the magnetic separation step

\begin{tabular}{|c|c|c|c|c|c|c|}
\hline Material & $\begin{array}{l}\text { Ratio } \\
(\%)\end{array}$ & $\begin{array}{l}\mathrm{Zn} \\
(\%)\end{array}$ & $\begin{array}{l}\mathrm{Fe} \\
(\%)\end{array}$ & $\begin{array}{l}\mathrm{SiO}_{2} \\
(\%)\end{array}$ & Mineralogy & Residue \\
\hline $\begin{array}{l}\text { Flotation } \\
\text { concentrate }\end{array}$ & - & 44.4 & 4.40 & $23.7 \%$ & $\begin{array}{l}\text { Hematite (3.3\%), } \\
\text { franklinite }(2.2 \%) \text {, } \\
\text { dolomite }(3.4 \%) \text {, } \\
\text { quartz }(1.3 \%) \\
\text { willemite/ } \\
\text { hemimorphite (89.6\%) }\end{array}$ & $\begin{array}{l}\text { Slimes (gypsum, } \\
\text { muscovite, etc) } \\
(\sim 90 \%) \text { quartz } \\
(6.0 \%) \\
\text { hematite }(6.7 \%)\end{array}$ \\
\hline $\begin{array}{l}\text { Non- } \\
\text { magnetic } \\
\text { concentrate }\end{array}$ & 90 & 50.8 & 5.35 & $23.0 \%$ & $\begin{array}{l}\text { Hematite }(0.3 \%)^{\mathrm{a}} \text {, } \\
\text { franklinite }(0.2 \%) \text {, } \\
\text { dolomite }(1.8 \%) \text {, } \\
\text { quartz }(1.0 \%) \\
\text { willemite/ } \\
\text { hemimorphite }(95.7 \%)\end{array}$ & $\begin{array}{l}\text { Slimes (gypsum) } \\
(\sim 85.5 \%) \\
\text { quartz }(7.2 \%) \\
\text { hematite }(5.7 \%)\end{array}$ \\
\hline $\begin{array}{l}\text { Magnetic } \\
\text { concentrate }\end{array}$ & 10 & 30.1 & 28.1 & $10.9 \%$ & $\begin{array}{l}\text { Hematite (35.1\%), } \\
\text { franklinite }(12.8 \%) \text {, } \\
\text { dolomite }(2.9 \%) \text {, } \\
\text { quartz }(1.5 \%) \\
\text { willemite }(46.3 \%)\end{array}$ & $\begin{array}{l}\text { Shematite (5.7\%), } \\
\text { franklinite (1.3\%), } \\
\text { quartz }(7.2 \%), \\
\text { slimes } \\
\text { (gypsum, 85.0\%) }\end{array}$ \\
\hline
\end{tabular}

${ }^{a}$ Very small hematite grains not measurable by optical microscopy. 


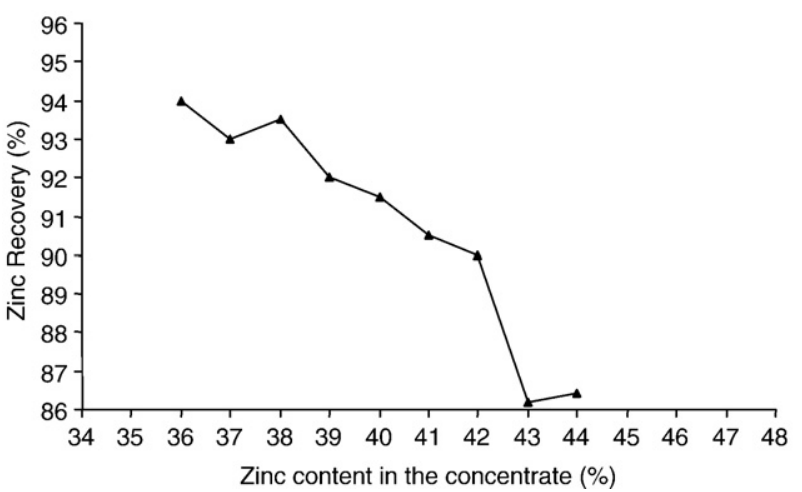

Fig. 13. Zinc mass recovery for different zinc contents in the concentrate.

such as Votorantim Metais in Brazil, the overall zinc recovery could be significantly increased by more than $8 \%$ when it is possible to increase the iron content in the flotation concentrate.

For those plants treating only zinc silicate concentrates, a different concept can be proposed using the iron in the zinc silicate concentrate to remove impurities. The simplified flowsheet of this new concept is showed in Fig. 14 which introduces a magnetic separation step performed on the flotation concentrate and produces two different phases. The first has a low-iron content $(\sim 5 \%)$ that accounts for $90 \%$ mass recovery (non-magnetic concentrate) (Table 4). This contains willemite/hemimorphite as the zinc zinc-containing phases, plus hematite, franklinite and goethite as source of iron. This product can be leached under mild conditions $\left(70^{\circ} \mathrm{C}\right)$ and dissolution of these iron minerals is not an issue (Table 4). A second fraction, with high-iron content ( 28\%) (magnetic concentrate) containing around 35\% hematite and $13 \%$ franklinite, requires stronger leaching conditions $\left(90{ }^{\circ} \mathrm{C}\right.$ ) so that part of the hematite is dissolved - with the iron precipitated afterwards when the $\mathrm{pH}$ is increased, removing the impurities. Leaching of the magnetic and non-magnetic concentrates produced high zinc recoveries ( $>98 \%$ ), similarly to that accomplished with the flotation concentrate, with the advantage that it is possible to produce a solution containing $>6 \mathrm{~g} / \mathrm{L} \mathrm{Fe}(\mathrm{III})$, sufficient for trace impurity removal (Souza, 2007). This demonstrates that the proposed conditions for leaching are satisfactory and can be applied on an industrial scale.

Several advantages can be foreseen in the proposed flowsheet. Firstly, the existing industrial facilities can be utilized to leach the nonmagnetic concentrate because leaching can be carried out in mild conditions. As a result, the concentrates with higher iron content could be processed without affecting zinc recovery; therefore dirtier concentrates could also be treated. Another advantage is that iron dissolution from the magnetic concentrate acts as a source of soluble iron for impurities removal in the purification step. This eliminates the need for sulphide concentrates in the same process and the efficient treatment of $100 \%$ zinc silicate concentrate becomes feasible.

\section{Conclusions}

The leaching of zinc silicate concentrates with high- and low-iron content was studied. Iron was found to be present as mainly hematite and franklinite. The rate of zinc extraction increased gradually with sulphuric acid concentration in the range 0.1 to $1 \mathrm{~mol} / \mathrm{L}$. The activation energy for leaching the high-iron concentrate was statistically similar to that observed for the low-iron material, which suggests that both solids have the same rate-controlling step. Increasing the iron content of the silicate from $5 \%$ to $9 \%$ does not result in a statistically significant reduction in zinc extraction. This enables more impure concentrates, in terms of iron content, to be treated in the hydrometallurgical plant. By magnetically separating the concentrate into a low low-iron and high high-iron fraction and treating the high high-iron fraction with acid at higher temperature, the overall zinc recovery could be increased by more than $8 \%$.

\section{Acknowledgments}

This work was supported by Votorantim Metais Zinc, "FINANCIADORA DE ESTUDOS E PROJETOS - FINEP", and Universidade Federal de Ouro Preto-UFOP. The CAPES scholarship to P. S. Pina and the assistance of Mr. J. A. Magalhães and Ms. H. K. Reis are gratefully acknowledged.

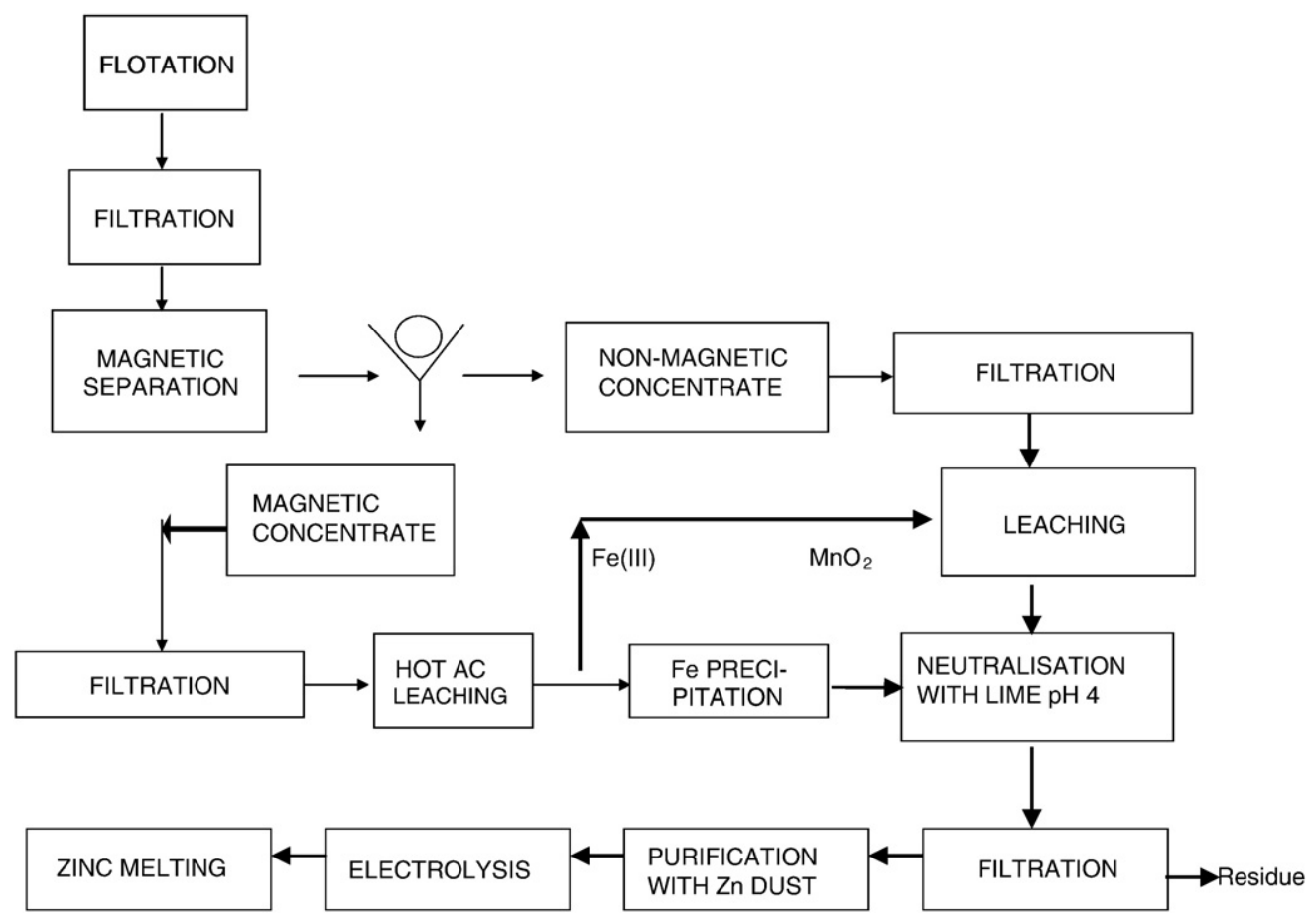

Fig. 14. New concept to treat flotation/magnetic silicate concentrate with high-iron content. 


\section{References}

Abdel-Aal, E.A., 2000. Kinetics of sulfuric acid leaching of low-grade zinc silicate ore. Hydrometallurgy 55 (3), 247-254.

Bodas, M.G., 1996. Hydrometallurgical treatment of zinc silicate ore from Thailand. Hydrometallurgy 40 (1-2), 37-49.

Brook-Hunt, 2005. In: Brook Hunt (Ed.), Mining and Metal Consultants, “Zinc Smelter Study". B.H.a.A. Ltd.

Copur, M., Özmetin, C., Özmetin, E., Kocakerim, M.M., 2004. Optimization study of the leaching of roasted zinc sulphide concentrate with sulphuric acid solutions. Chemical Engineering and Processing 43 (8), 1007-1014.

Espiari, S., Rashchi, F., Sadrnezhad, S.K., 2006. Hydrometallurgical treatment of tailings with high zinc content. Hydrometallurgy 82 (1-2), 54-62.

Georgiou, D., Papangelakis, V.G., 1998. Sulphuric acid pressure leaching of a limonitic laterite: chemistry and kinetics. Hydrometallurgy 49 (1-2), 23-46.

Pappu, A., Saxena, M., Asolekar, S.R., 2006. Jarosite characteristics and its utilisation potentials. Science of the Total Environment 359 (1), 232-243.

Raghavan, R., Mohanan, P.K., Patnaik, S.C., 1998. Innovative processing technique to produce zinc concentrate from zinc leach residue with simultaneous recovery of lead. Hydrometallurgy 48 (2), 225-237.
Sohn, H.Y., Wadsworth, M.E., 1979. Rate Processes of Extractive Metallurgy. Plenum Press, New York. 472 pp.

Souza, A.D., 2000. Integration Process of the Treatment of Concentrates or Zinc Silicates Ore and Roasted Concentrate of Zinc Sulphides.

Souza, A.D., 2007. Cinética de lixiviação dos concentrados de zinco utilizados na Votorantim Metais. Universidade Federal de Ouro Preto, Ouro Preto, MG, Brazil. 112 pp.

Souza, A.D., Pina, P.S., Lima, E.V.O., Silva, C.A., Leao, V.A., 2007. A kinetic study of the sulphuric acid leaching of a zinc silicate calcine. Hydrometallurgy 89, 337-345.

Szekely, J., Evans, J.W., Sohn, H.Y., 1976. Gas Solid Reactions. Academic Press, New York. $400 \mathrm{pp}$.

Terry, B., Monhemius, A.J., 1983. Acid dissolution of willemite $\left((\mathrm{Zn}, \mathrm{Mn})_{2} \mathrm{SiO}_{4}\right)$ and hemimorphite $\left(\mathrm{Zn}_{4} \mathrm{Si}_{2} \mathrm{O}_{7}(\mathrm{OH})_{2} \mathrm{H}_{2} \mathrm{O}\right)$. Metall. Trans.B - Process Metallurgy 14 (3), 335-346.

Youcai, Z., Stanforth, R., 2000. Extraction of zinc from zinc ferrites by fusion with caustic soda. Minerals Engineering 13 (13), 1417-1421. 